cent in total microfilaræmia was found. Out of a total of 471 persons examined from six communities, 6.7 were positive for microfilariæ, a reduction of approximately 60 per cent over the 1948 findings in the same areas. Of even greater significance is the fact that no microfilarial counts greater than 14 per $60 \mathrm{c.mm}$. of blood were found, and 88.7 per cent of the positives showed counts of ten or less microfilariæ per $60 \mathrm{c.mm}$. Counts within this range are considered non-infective for mosquitoes. In contrast, counts as high as 360 microfilariæ per $60 \mathrm{c.mm}$. were found in the pre-treatment survey, and the number of positives showing ten or less microfilariæ per 60 c.mm. was $27 \cdot 1$ per cent.

We consider this an effective demonstration of the potentialities of mass therapy with 'Hetrazan' for reducing drastically the chances of mosquito infections in closely circumscribed endemic areas for Bancroftian filariasis. The systemic reactions encountered in this treatment programme were mild and of short duration, and but a small proportion of the population reported fever, malaise, headache or localized reactions of allergic nature which some. times accompany treatment with this compound. These are thought to be brought about by a release of filarial protein when worms are killed. Persons not harbouring filariæ rarely complained of symptoms at the prescribed dosage.

Although it is known that all inhabitants of the island did not take 'Hetrazan', and many probably fell short of the full course of treatment prescribed, the mass application of this chemotherapeutic method of attack against Bancroftian filariasis has been shown to be practical and effectual. A more detailed report of the methods used and results obtained is now being prepared.

Lederle Laboratories Division,

Redginal HewitT

American Cyanamid Company,

Pearl River, New York. July 28.

\section{Assay of the Nutritive Value of a Protein by its Effect on Liver Cytoplasm}

THE fact that the cytoplasm content of the liver cell is determined by the quality and quantity of the dietary protein has recently been utilized for the assay of the nutritive value of a protein'. A measure of the cytoplasm content of the liver cell was obtained by estimating either non-glycogen non-lipid liver solids or liver protein per $100 \mathrm{gm}$. body-weight in female rats. It was then suggested that the variability of the method might be reduced by referring the amount of liver protein not to $100 \mathrm{gm}$. body. weight but to liver deoxyribonucleic acid, the only constituent of the liver which appears to be independent of variations in dietary protein ${ }^{2}$. The possibility of using male instead of female rats was also considered.

The statistical examination of the results obtained on 44 male and 41 female rats led to the following conclusions. The replacement of the ratio $\mathrm{mgm}$. liver protein/100 gm. initial body-weight (I) by the ratio mgm. liver protein/mgm. deoxyribonucleic acid phosphorus (II) does not improve the precision of the method. First, ratio II is not better correlated with dietary protein nitrogen intake than is ratio $I$. Secondly, in male rats, ratio II, but not ratio $\mathbf{I}$, increases with rising body-weight, independently of dietary protein intake ${ }^{2}$. Finally, the determination. of ratio II is considerably more difficult and timeconsuming than that of ratio $I$.

It has been confirmed that both ratios I and II vary directly with the logarithms of dietary casein nitrogen intake (mgm./100 gm. initial body-weight/24 hr.) when casein nitrogen intakes between $36 \mathrm{mgm}$. and $480 \mathrm{mgm}$. are taken into consideration. If, however, the higher intakes are excluded and the regressions are calculated for casein nitrogen intakes between 0 and $190 \mathrm{mgm}$. casein nitrogen, the relationship between the two ratios and the casein nitrogen intake is better represented linearly.

So far as the selection of the most suitable method for the assay of the nutritive value of a protein by its effect on liver cytoplasm is concerned, the following points should be taken into consideration. (1) The regression coefficients are smaller for female than for male rats, which latter are therefore more sensitive to variations in dietary protein intake ${ }^{2}$. (2) A dietary protein intake of more than $200 \mathrm{mgm}$. casein nitrogen / $100 \mathrm{gm}$. body-weight $/ 24 \mathrm{hr}$., or correspondingly higher intakes of protein of lower nutritive value, is very often not practicable. In such instances it would be advantageous to use the 'common zero 5-point' design introduced by Wood ${ }^{3}$ for assays in which the response is linearly related to the dose. (3) Although small variations in bodyweight have no significant effect on the regression of liver protein $/ 100 \mathrm{gm}$. body-weight on dietary protein nitrogen intake, the rats should be selected at random with regard to their body-weight and the effect tested. With increasing body-weight, the ratio liver protein/100 gm. body-weight decreases more rapidly in female than in male rats. (4) Total liver nitrogen can probably replace true liver protein, since the nonprotein nitrogen is a relatively small fraction of total nitrogen. The determination of total nitrogen would be more rapid than that of true liver protein or of non-glyeogen non-lipid liver solids ${ }^{2,4}$.

Rosa M. Campbell

(Carnegie Senior Scholar)

H. W. Kosterlitz

Physiology Department,

University of Aberdeen. Aug. 8.

${ }^{1}$ Kosterlitz, H. W. and Campbell, R. M. Nature, 15\%, 628 (1946). Campbell, R. M., and Kosterlitz, H. W., J. Physiol., 107, 383 (1948).

${ }^{2}$ Campbell, R. M., and Kosterlitz, H. W., J. Endocrinol. (in the press) Wood, E. C., Analyst, 71, 1 (1946).

‘ Kosterlitz, H. W., J. Physiol., 106, 194 (1947).

\section{Cultivation of Rabbit Eggs and Cumuli for Phase-Contrast Microscopy}

Phase-contrast microscopy has been used to study cultures of chick embryonic tissue ${ }^{1}$ and mouse spleen ${ }^{2}$, but not, hitherto, for observing cultures of mammalian eggs. The methods described by Pincus ${ }^{3}$ and Chang 4 for cultivation of rabbit eggs are not designed for phase microscopy, and histological procedures are required to show the nuclei. Austin and Smiles ${ }^{5}$ demonstrated the value of the phase-contrast microscope in a study of rat eggs freshly recovered from the Fallopian tubes; nuclei could be seen in the intact eggs, and much more clearly after they had been somewhat flattened between slide and coverslip.

A technique has been devised for culturing rabbit eggs for repeated observation by phase-contrast 